\author{
Roman JASKULSKI ${ }^{1}$ \\ Michal A. GLINICKI ${ }^{2}$ \\ Mariusz DABROWSKI ${ }^{3}$ \\ Zbigniew RANACHOWSKI ${ }^{4}$ \\ Maciej SOBCZAK ${ }^{5}$
}

\title{
MONITOROWANIE PARAMETRÓW TERMICZNYCH PROCESU TWARDNIENIA BETONÓW OSŁONOWYCH
}

\begin{abstract}
W artykule przedstawiono wyniki badań parametrów termicznych procesu twardnienia mieszanek betonowych, z których dwie wykonano z wykorzystaniem kruszyw stosowanych w produkcji betonów osłonowych (kruszywo magnetytowe oraz serpentynitowe), a trzecią, referencyjną, z wykorzystaniem kruszywa amfibolitowego. Na podstawie analizy dokonanych pomiarów temperatury wyznaczono parametry procesu twardnienia betonu (m.in. maksymalny przyrost temperatury, maksymalny gradient $\mathrm{i}$ in.). Jednocześnie rozwiązując numerycznie tzw. zagadnienie odwrotne wyznaczono parametry cieplne betonu w trakcie pierwszych 72 godzin twardnienia. Tą samą metodą wyznaczono również wartości funkcji źródła ciepła, a następnie na jej podstawie oszacowano ilość ciepła wydzieloną w procesie hydratacji cementu. Uzyskano dobrą jakościową zgodność postaci funkcji źródła ciepła oraz wykresów zmian temperatury w mieszankach. W toku analiz uzyskanych wyników wyraźnie zaznaczył się wpływ zróżnicowania parametrów cieplnych zastosowanych kruszyw. W przypadku mieszanki z kruszywem serpentynitowym dały się także zauważyć istotne różnice w przebiegu przyrostu temperatury (opóźnienie) w stosunku do pozostałych mieszanek.
\end{abstract}

Słowa kluczowe: młody beton, beton osłonowy, ciepło hydratacji, ciepło właściwe, współczynnik przewodzenia ciepła

${ }^{1}$ Autor do korespondencji/corresponding author: Roman Jaskulski, Instytut Podstawowych Problemów Techniki PAN, 02-106 Warszawa, ul. Pawińskiego 5B, tel.: +48 22826 12 81, e-mail: rjask@ippt.pan.pl

${ }^{2}$ Michał A. Glinicki, Instytut Podstawowych Problemów Techniki PAN, 02-106 Warszawa, ul. Pawińskiego 5B, tel.: +48 2282612 81, e-mail: mglinic@ippt.pan.pl

${ }^{3}$ Mariusz Dąbrowski, Instytut Podstawowych Problemów Techniki PAN, 02-106 Warszawa, ul. Pawińskiego 5B, tel.: +48 2282612 81, e-mail: mdabrow@ippt.pan.pl

4 Zbigniew Ranachowski, Instytut Podstawowych Problemów Techniki PAN, 02-106 Warszawa, ul. Pawińskiego 5B, tel.: +48 2282612 81, e-mail: zranach@ippt.pan.pl

5 Maciej Sobczak, Instytut Podstawowych Problemów Techniki PAN, 02-106 Warszawa, ul. Pawińskiego 5B, tel.: +48 2282612 81, e-mail: msobczak@ippt.pan.pl 


\section{Wprowadzenie}

Betonowe konstrukcje osłonowe w energetyce jądrowej ze względu na swoją specyfikę i rolę zwykle wykonywane są jako konstrukcje masywne. W tego rodzaju konstrukcjach kluczowe znaczenia ma ilość ciepła wydzielanego podczas procesów hydratacji cementu oraz sposób jego propagacji w twardniejącym młodym betonie [7]. Krytycznym okresem w przypadku konstrukcji masywnych są pierwsze doby po betonowaniu, kiedy młody beton nie ma jeszcze wystarczającej wytrzymałości, żeby przenieść naprężenia rozciągające powstałe w wyniku powstających gradientów temperatury i kiedy jednocześnie wydzielane są największe ilości ciepła, a przez to ryzyko powstania szkodliwych gradientów, i w konsekwencji rys, jest największe.

Beton wykorzystywany do konstrukcji osłon biologicznych reaktorów jądrowych musi charakteryzować się niską przepuszczalnością zarówno cieczy, jak i gazów $[1,2,10]$, żeby zapobiec wyciekowi radioaktywnemu w przypadku awarii reaktora. Wymagań takich nie spełni materiał, w którym na etapie twardnienia powstały rysy. W zapobieganiu ich powstawania ważną rolę pełni odpowiedni dobór materiałów. W tym nie tylko cementu o odpowiednio niskim cieple hydratacji, ale także kruszywa, którego właściwości cieplne (tj. ciepło właściwe i przewodność cieplna) w największym stopniu decydują o właściwościach gotowej mieszanki.

Równie istotna jest wiedza na temat zmian właściwości cieplnych młodego betonu w czasie procesu jego twardnienia. Znajomość ich zmienności w czasie może pozwolić na precyzyjne modelowanie pól temperatury w konstrukcjach masywnych i sterowanie nimi. Takie zagadnienie zostało podjęte między innymi w pracy [8].

Celem niniejszego artykułu jest przeanalizowanie wyników monitoringu zmian temperatury w twardniejących mieszankach betonów w ciągu pierwszych 72 godzin od zabetonowania oraz wpływu zastosowanych kruszyw do betonów osłonowych (o zróżnicowanych właściwościach cieplnych) na rozwój i propagację ciepła w twardniejącym materiale.

\section{Materiały i metodyka badań}

\subsection{Skład mieszanek}

Badane mieszanki betonowe zostały wykonane $\mathrm{z}$ wykorzystaniem cementu CEM I 42,5 R z cementowni Kujawy. Jako kruszywa drobnego użyto piasku kwarcowego frakcji 0-2 mm. Zastosowano trzy rodzaje kruszywa grubego. Do wykonania betonu odniesienia (oznaczonego CI-A) użyto grysu amfibolitowego o uziarnieniu 2-8 $\mathrm{mm}$ oraz 8-16 $\mathrm{mm}$. Do wykonania betonów osłonowych użyto kruszywa magnetytowego frakcji 0-5 $\mathrm{mm}$ i 0-16 $\mathrm{mm}$ (beton CI-M) oraz kruszywa serpentynitowego frakcji 2-8 mm i 8-16 mm (beton CI-S). W celu 
uzyskania podobnej konsystencji mieszanek w przypadku betonów CI-M i CI-S został zastosowany superplastyfikator. Podstawowe informacje na temat składu wykonanych mieszanek betonowych zamieszczono w tablicy 1 .

Tablica 1. Skład badanych mieszanek

Table 1. Composition of concrete mixtures

\begin{tabular}{|l|c|c|c|}
\hline \multirow{2}{*}{ Skladnik } & \multicolumn{3}{|c|}{ Mieszanka } \\
\cline { 2 - 4 } & CI-A & CI-M & CI-S \\
\hline Cement CEM I 42,5 R $\left[\mathrm{kg} / \mathrm{m}^{3}\right]$ & 400 & 400 & 400 \\
\hline Woda $\left[1 / \mathrm{m}^{3}\right]$ & 200 & 200 & 200 \\
\hline Piasek 0-2 $\mathrm{mm}\left[\mathrm{kg} / \mathrm{m}^{3}\right]$ & 552 & 552 & 552 \\
\hline Grys amfibolitowy $2-8 \mathrm{~mm}\left[\mathrm{~kg} / \mathrm{m}^{3}\right]$ & 585 & --- & --- \\
\hline Grys amfibolitowy $8-16 \mathrm{~mm}\left[\mathrm{~kg} / \mathrm{m}^{3}\right]$ & 698 & --- & --- \\
\hline Kruszywo magnetytowe $0-5 \mathrm{~mm}\left[\mathrm{~kg} / \mathrm{m}^{3}\right]$ & --- & 625 & --- \\
\hline Kruszywo magnetytowe $0-16 \mathrm{~mm}\left[\mathrm{~kg} / \mathrm{m}^{3}\right]$ & --- & 1500 & --- \\
\hline Kruszywo serpentynitowe $2-8 \mathrm{~mm}\left[\mathrm{~kg} / \mathrm{m}^{3}\right]$ & --- & --- & 846 \\
\hline Kruszywo serpentynitowe $8-16 \mathrm{~mm}\left[\mathrm{~kg} / \mathrm{m}^{3}\right]$ & --- & --- & 305 \\
\hline Plastyfikator (na bazie fosfonianów) $[\% \mathrm{~m}$. c.] & --- & 0,3 & 0,8 \\
\hline
\end{tabular}

\subsection{Przebieg badania}

Badane mieszanki po przygotowaniu umieszczone zostały w urządzeniu pomiarowym, którego schemat przedstawiono na rys. 1. Urządzenie podczas pomiaru znajdowało się $\mathrm{w}$ pomieszczeniu, w którym średnia temperatura oscylowała wokół $22^{\circ} \mathrm{C}$, a jej dobowe wahania mieściły się w zakresie $3-4^{\circ} \mathrm{C}$.

Ze względu na sposób rozmieszczenia izolacji znajdującej się wokół badanej porcji mieszanki, ciepło wydzielane w procesach hydratacji cementu było odprowadzane w dominującej większości przez nieizolowaną powierzchnię górną. Była ona w trakcie badania przykryta jedynie cienką warstwą folii polietylenowej mającą za zadanie ograniczyć wysychanie twardniejącej mieszanki. W ten sposób wymuszono w próbce jednokierunkowy przepływ ciepła, co skutkowało m.in. pojawieniem się pionowego gradientu temperatury.

Temperaturę mieszanki podczas twardnienia rejestrowały mierniki rozmieszczone wzdłuż pionowej osi środkowej urządzenia. Wyniki pomiarów zapisywane były automatycznie w odstępach co 1 minutę przez około 72 godziny. Przykładowy zapis uzyskany w przypadku mieszanki CI-A przedstawiono na rys. 2. Na wykresie tym widać, że najwyższą temperaturę w mieszance zarejestrował miernik umieszczony na wysokości $20 \mathrm{~cm}$ nad dnem urządzenia. Prawidłowość ta powtórzyła się we wszystkich badanych mieszankach, dlatego wyniki pomiarów na tej wysokości przyjęto jako najbardziej miarodajne. Stanowiły one podstawę do większość przeprowadzanych dalej analiz. 


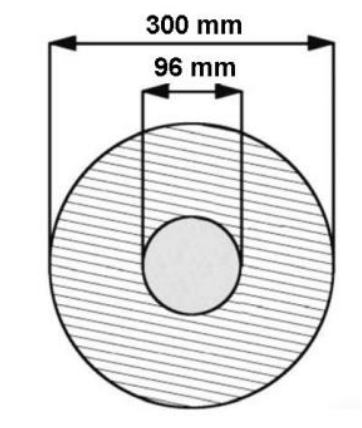

miernik temperatury

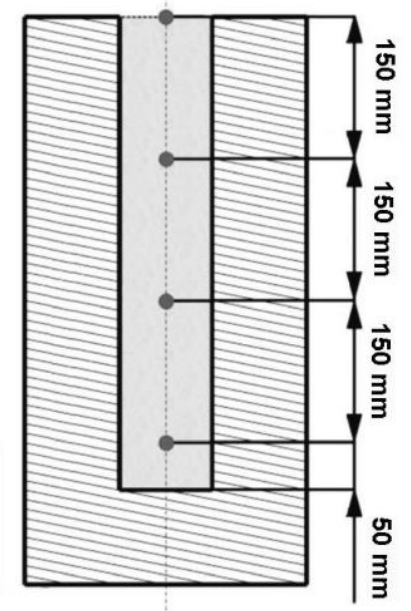

Rys. 1. Schemat urządzenia do badania jednowymiarowego przepływu ciepła

Fig. 1. Schematic illustration of a one-dimensional heat flow test equipment

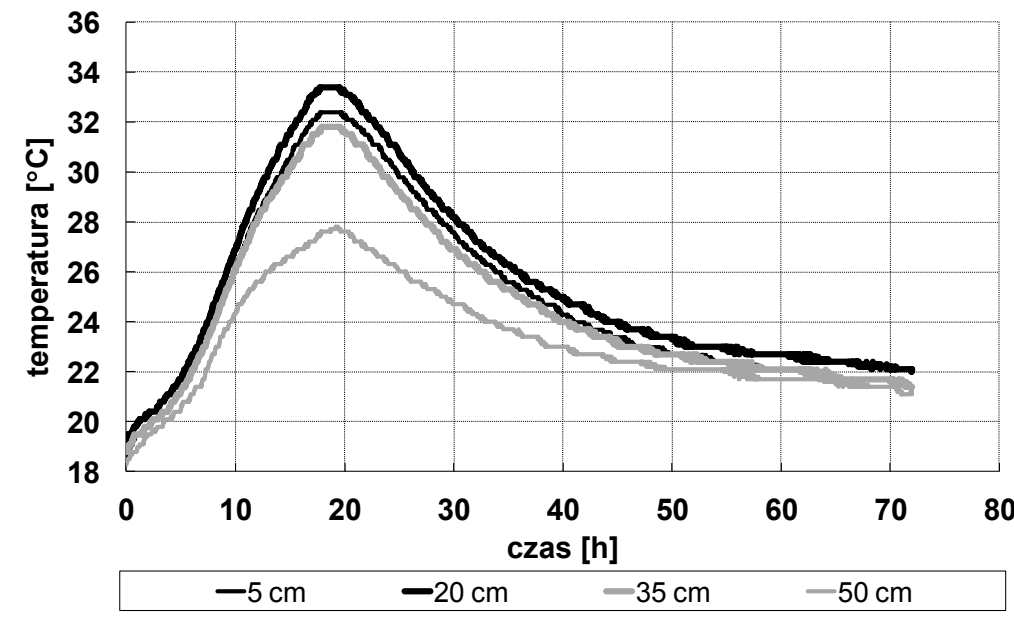

Rys. 2. Wykres zmian temperatury twardniejącego betonu w mieszance CI-A

Fig. 2. Temperature changes during hardening of the CI-A mixture

Uzyskane zapisy zmian temperatury ze wszystkich czujników, łącznie z rejestrowaną równocześnie temperaturą otoczenia, posłużyły do wyznaczenia parametrów termicznych twardniejących betonów: ciepła właściwego, współczynnika przewodzenia ciepła oraz wartości funkcji ciepła twardnienia. Wartości te wyznaczono numerycznie rozwiązując tzw. problem odwrotny. Szczegółowy opis tej metody, jej założeń oraz algorytmu zamieszczono w pracy [9]. 


\section{Wyniki i ich dyskusja}

Ze względu na duże różnice temperatury początkowej badanych mieszanek jako podstawę analiz przyjęto nie bezwzględne zmiany temperatury, ale jej przyrosty w stosunku do temperatury początkowej. Wykresy przyrostów temperatury poszczególnych mieszanek przedstawiono na rys. 3. Dane, które posłużyły do sporządzenia prezentowanych wykresów, poddano analizie wyznaczając $\mathrm{m}$. in. maksymalną wartość przyrostu temperatury oraz maksymalny przyrost temperatury w czasie (badany w interwałach 15-minutowych).

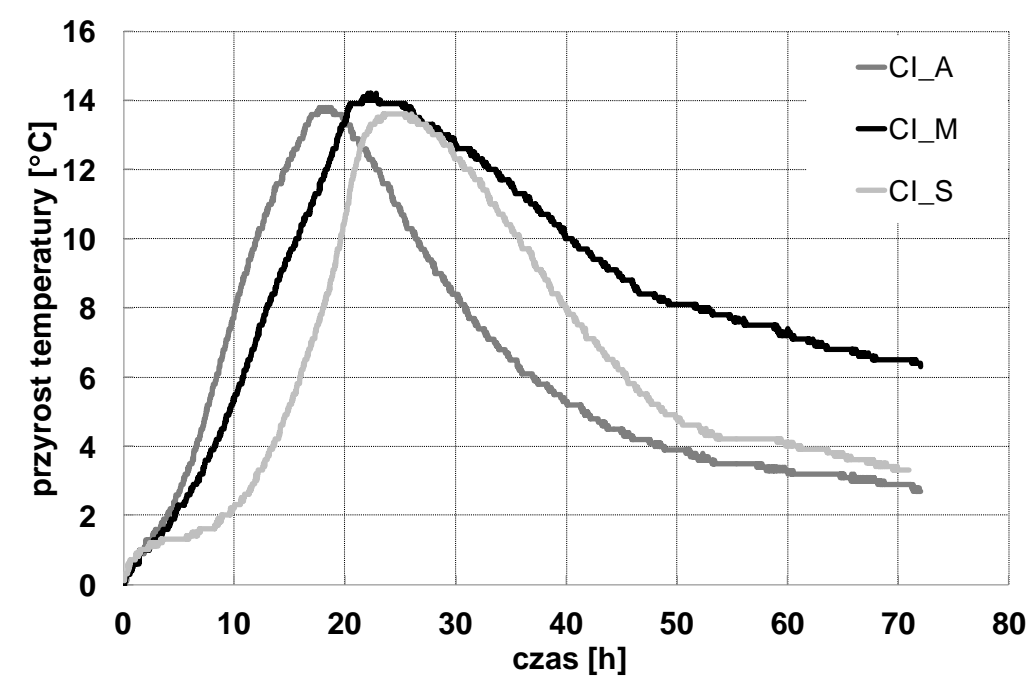

Rys. 3. Przyrost temperatury w badanych mieszankach (wysokość $20 \mathrm{~cm}$ od dna)

Fig. 3. Temperature growth in tested mixtures (at $20 \mathrm{~cm}$ over the bottom)

Ponadto na podstawie wszystkich zarejestrowanych wartości temperatury określono wartość maksymalnego gradientu temperatury, jaki powstał w mieszance oraz najwyższą bezwzględną temperaturę, jaką osiągnęła mieszanka. W przypadku wszystkich wymienionych wyżej wartości określono również czas ich wystąpienia. Jeśli któraś z nich występowała wielokrotnie, określono w jej przypadku tylko czas jej pierwszego wystąpienia. Zestawienie ww. parametrów znajduje się w tablicy 2.

Analiza wyników wskazuje, że najwyższą wartość temperatury osiągnęła mieszanka CI-S, ale jednocześnie w jej przypadku zanotowano najniższy względny przyrost temperatury. Na drugim biegunie znalazła się mieszanka CI-M, która osiągnęla najniższą wartość maksymalnej temperatury oraz najwyższy jej względny przyrost. Zanotowane różnice między poszczególnymi mieszankami są jednak niewielkie i w przypadku przyrostu temperatury sięgają $0,6^{\circ} \mathrm{C}$. 
Tablica 2. Parametry termiczne procesu twardnienia mieszanek betonowych

Table 2. Thermal parameters of concrete mixtures hardening process

\begin{tabular}{|l|c|c|c|}
\hline \multirow{2}{*}{ Parametr } & \multicolumn{3}{|c|}{ Mieszanka } \\
\cline { 2 - 4 } & CI-A & CI-M & CI-S \\
\hline Temperatura maksymalna $\mathrm{T}_{\max }\left[{ }^{\circ} \mathrm{C}\right]$ & 33,3 & 31,4 & 35,0 \\
\hline czas wystąpienia $\mathrm{t}\left(\mathrm{T}_{\max }\right)[\mathrm{h}]$ & 17,67 & 22,07 & 23,43 \\
\hline Maksymalny przyrost temperatury $(\Delta \mathrm{T})_{\max } *\left[{ }^{\circ} \mathrm{C}\right]$ & 13,8 & 14,2 & 13,6 \\
\hline czas wystąpienia $\mathrm{t}(\Delta \mathrm{T})_{\max } *[\mathrm{~h}]$ & 17,67 & 22,07 & 23,43 \\
\hline Maksymalny gradient temperatury $(\nabla \mathrm{T})_{\max }\left[{ }^{\circ} \mathrm{C} / \mathrm{m}\right]$ & 28,0 & 21,3 & 30,7 \\
\hline czas wystąpienia $\mathrm{t}\left((\nabla \mathrm{T})_{\max }\right)[\mathrm{h}]$ & 17,35 & 21,33 & 20,88 \\
\hline Maks. szybkość wzrostu temperatury $(\Delta \mathrm{T} / \Delta \mathrm{t})_{\max } * *\left[{ }^{\circ} \mathrm{C} / \mathrm{h}\right]$ & 1,6 & 1,6 & 2,8 \\
\hline czas wystąpienia $\mathrm{t}\left((\Delta \mathrm{T} / \Delta \mathrm{t})_{\max }\right)^{* *}[\mathrm{~h}]$ & 2,00 & 1,63 & 20,58 \\
\hline
\end{tabular}

*) czujnik na wysokości $20 \mathrm{~cm}$ od dna

**) $\Delta \mathrm{t}=15 \mathrm{~min}$; czujnik na wysokości $20 \mathrm{~cm}$ od dna

Jeśli chodzi o czas pojawienia się maksimum temperatury, to najwcześniej zostało ono osiągnięte w mieszance CI-A, a najpóźniej w mieszance CI-S. Ta druga mieszanka ma też widoczne na wykresie przyrostu temperatury niewielkie plateau. Ponieważ do jej wykonania wykorzystano największą ilość superplastyfikatora, $(0,8 \%$ m.c.) możliwe jest, że ten właśnie dodatek spowodował przesunięcie momentu rozpoczęcia wiązania mieszanki i tym samym osiągnięcia przez nią maksymalnego przyrostu temperatury.

Najwyższy gradient temperatury wystąpił w mieszance CI-S i wyniósł $30,7^{\circ} \mathrm{C} / \mathrm{m}$, a najniższy w mieszance CI-M, gdzie wyniósł $21,3^{\circ} \mathrm{C} / \mathrm{m}$. Obie wartości gradientów wystąpiły zanim mieszanki osiągnęły swoje maksima temperatury. Bardzo wyraźna różnica między obliczonymi wartościami gradientów jest skutkiem różnicy właściwości termicznych wykorzystanych kruszyw. Jak wynika z pracy [6] betony z kruszywem magnetytowym charakteryzują się wysokim współczynnikiem przewodności cieplnej sięgającym nawet powyżej $3,0 \mathrm{~W} / \mathrm{m} \cdot \mathrm{K}$, podczas gdy betony z kruszywem serpentynitowym osiągają dużo niższe wartości tego współczynnika, około $1,9 \mathrm{~W} / \mathrm{m} \cdot \mathrm{K}$.

Maksymalna zanotowana szybkość przyrostu temperatury w przypadku mieszanki CI-S wyraźnie odbiega od pozostałych dwóch zarówno samym tempem $\left(2,8^{\circ} \mathrm{C} / \mathrm{h}\right.$ wobec $1,6^{\circ} \mathrm{C} / \mathrm{h}$ w przypadku obu pozostałych), jak też czasem, w którym ten najszybszy przyrost nastąpił. Mieszanki CI-A i CI-M osiągnęły maksymalne tempo przyrostu temperatury w ciągu pierwszych dwóch godzin od rozpoczęcia pomiarów, a mieszanka CI-S prawie po upływie doby. Trudno na tym etapie badań przesądzić, co mogło być przyczyną tego opóźnienia, ale przypuszczalnie był to efekt uboczny zastosowania znacznej ilości superplastyfikatora. 
Parametry termiczne mieszanek określone $\mathrm{w}$ wyniku rozwiązania zagadnienia odwrotnego zamieszczono $w$ tablicy 3 . Znajdują się w niej wartości ciepła właściwego mieszanek $c_{p}$ oraz ich współczynnika przewodności cieplnej $\lambda$ na początku procesu twardnienia oraz po upływie 72 godzin. Analiza otrzymanych wartości prowadzi do wniosku, że w przypadku analizowanych mieszanek w każdym przypadku wzrosła wartość przewodności cieplnej, a wartości ciepła właściwego w dwóch przypadkach spadły (mieszanki CI-A oraz CI-S), a w jednym wzrosły (mieszanka CI-M). Należy podkreślić, że prezentowane wyniki uzyskano po niewielkiej liczbie 12 iteracji procedury obliczeniowej w przypadku każdej mieszanki, co zaowocowało dużą zmiennością wyników.

Tablica 3. Parametry termiczne twardniejących mieszanek określone na podstawie rozwiązania zagadnienia odwrotnego

Table 3. Thermal parameters of the hardening concrete mixtures as a result of the inverse problem solution

\begin{tabular}{|l|c|c|c|}
\hline \multirow{2}{*}{ Parametr } & \multicolumn{3}{|c|}{ Mieszanka } \\
\cline { 2 - 4 } & CI-A & CI-M & CI-S \\
\hline Ciepło właściwe $\mathrm{c}_{\mathrm{p}}(\mathrm{t}=0) \quad[\mathrm{J} / \mathrm{kg} \cdot \mathrm{K}]$ & $960 \pm 45$ & $870 \pm 51$ & $1088 \pm 18$ \\
\hline Ciepło właściwe $\mathrm{c}_{\mathrm{p}}(\mathrm{t}=72 \mathrm{~h})[\mathrm{J} / \mathrm{kg} \cdot \mathrm{K}]$ & $702 \pm 4$ & $894 \pm 18$ & $956 \pm 80$ \\
\hline $\begin{array}{l}\text { Współczynnik przewodności cieplnej } \\
\lambda(\mathrm{t}=0)[\mathrm{W} / \mathrm{m} \cdot \mathrm{K}]\end{array}$ & $2,48 \pm 0,22$ & $3,41 \pm 0,32$ & $2,74 \pm 0,06$ \\
\hline $\begin{array}{l}\text { Współczynnik przewodności cieplnej } \\
\lambda(\mathrm{t}=72 \mathrm{~h})[\mathrm{W} / \mathrm{m} \cdot \mathrm{K}]\end{array}$ & $2,68 \pm 0,07$ & $3,68 \pm 0,11$ & $2,78 \pm 0,05$ \\
\hline Ciepło twardnienia betonu $[\mathrm{kJ} / \mathrm{kg}]$ & $46,3 \pm 1,4$ & $37,1 \pm 1,1$ & $59,9 \pm 1,3$ \\
\hline Ciepło twardnienia cementu $[\mathrm{J} / \mathrm{g}]$ & $282 \pm 8$ & $304 \pm 9$ & $345 \pm 7$ \\
\hline Wartość funkcji celu $[-]$ & $18,5 \pm 3,7$ & $15,6 \pm 3,1$ & $13,1 \pm 1,9$ \\
\hline
\end{tabular}

W tablicy tej podano też wartości ciepła twardnienia obliczone na jednostkę masy betonu i cementu. Wartości te również zostały obliczone $\mathrm{w}$ procedurze rozwiązania zagadnienia odwrotnego na podstawie określonych numerycznie wartości funkcji mocy źródła ciepła wyrażonej $\mathrm{w} \mathrm{W} / \mathrm{m}^{3}$. Wartości te obliczone zostały w 19 punktach znajdujących się w równych odstępach czasowych co 4 godziny. Wykresy funkcji uzyskanych w przypadku badanych mieszanek z pomocą tej metody przedstawiono na rys. 4 .

Otrzymane funkcje scałkowano graficznie otrzymując w ten sposób całkowitą wydzieloną ilość ciepła na $1 \mathrm{~m}^{3}$ mieszanki. Uwzględniając gęstość mieszanki i zawartość cementu obliczono ciepło twardnienia przeliczone odpowiednio na $1 \mathrm{~kg}$ masy mieszanki oraz na $1 \mathrm{~g}$ masy cementu.

$\mathrm{W}$ tablicy 3 zamieszczono również obliczane w procedurze rozwiązywania zagadnienia odwrotnego wartości tzw. funkcji celu. Jest to funkcja pozwalająca ocenić jakość znalezionego rozwiązania. Minimalizacja jej wartości jest celem procedur optymalizacyjnych poszukujących rozwiązań zagadnienia odwrotnego. 


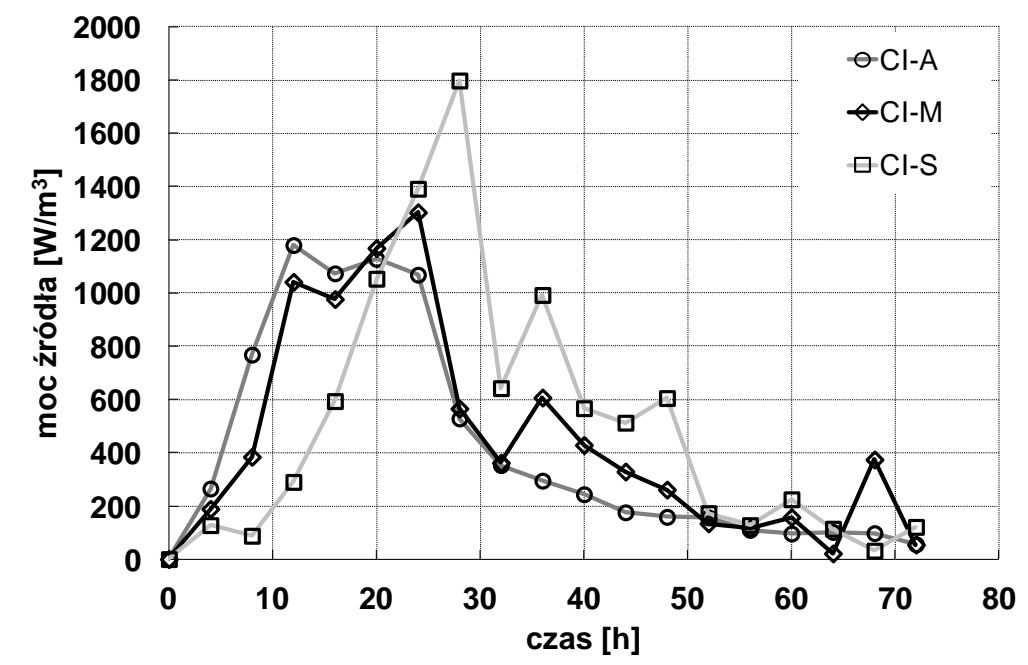

Rys. 4. Funkcja emisji ciepła jako wynik rozwiązania zagadnienia odwrotnego

Fig. 4. Heat release function as a result of the inverse problem solution

Informacja o jej wartości jest przydatna przy interpretowaniu m.in. prezentowanych wyników obliczeń ciepła twardnienia cementu. Ponieważ we wszystkich mieszankach zastosowano ten sam cement, całkowita ilość ciepło wydzielone podczas jego hydratacji powinna kształtować się na podobnym poziomie. $\mathrm{W}$ przypadku rozbieżności, które widać $\mathrm{w}$ wynikach zamieszczonych $\mathrm{w}$ tablicy 3 , jako najbardziej miarodajne należy uznać wartości uzyskane w przypadku mieszanki CI-S (345 J/g), w przypadku której wartość funkcji celu jest najniższa.

\section{Wnioski}

Przeprowadzone pomiary oraz ich analiza pozwoliły sformułować następujące wnioski.

1. Stwierdzono istotny wpływ zastosowania kruszyw wykorzystywanych w betonach osłonowych na wartość powstałego w mieszance gradientu temperatury. Wyniósł on od $21,3^{\circ} \mathrm{C} / \mathrm{m}$ w przypadku mieszanki $\mathrm{CI}-\mathrm{M}$ do $30,7^{\circ} \mathrm{C} / \mathrm{m}$ w przypadku mieszanki CI-S.

2. Nie stwierdzono istotnego wpływu zastosowanego kruszywa na wartość maksymalnego przyrostu temperatury $\mathrm{w}$ mieszance. Zarejestrowane wartości maksymalne nie różniły się od siebie o więcej niż $0,6^{\circ} \mathrm{C}$.

3. Rozwiązanie problemu odwrotnego w oparciu o wyniki ciągłego pomiaru temperatury przy wymuszonym jednowymiarowym przepływie ciepła pozwala określić charakter funkcji źródła ciepła oraz całkowitą ilość ciepła wygenerowaną przez procesy hydratacji cementu. W przypadku zastosowanego cementu przyjęto, że wynosi ona $345 \mathrm{~J} / \mathrm{g}$ cementu. 
Stosowane $\mathrm{w}$ betonach osłonowych kruszywa istotnie różnicują parametry termiczne tychże betonów w stosunku do betonów zwykłych a w konsekwencji także sposób propagacji ciepła w konstrukcjach masywnych. Z tego względu wszelkie obliczenia cieplne tego typu betonów powinny uwzględniać specyfikę kruszyw i nie należy ich opierać na powszechnie znanych parametrach wyznaczonych w przypadku betonów zwykłych.

\section{Podziękowania}

Referat zostat przygotowany $w$ ramach Projektu „Trwałość $i$ skuteczność betonowych oston przed promieniowaniem jonizujacym w obiektach energetyki jadrowej" (PBSII/A2/15/2014) finansowanego przez Narodowe Centrum Badań i Rozwoju.

\section{Literatura}

[1] Bamonte, P.; Gambarova, P.G. (2014) Properties of concrete required in nuclear power plants". W: Infrastructure Systems for Nuclear Energy; Hsu, T.T.C., Wu, C.L., Lin, J.-L., Eds.; John Wiley \& Sons, Hobokon, 2014, s. 409-438.

[2] Benboudjema F., Torrenti, J.M.: Early age behaviour of concrete nuclear containments, Nucl. Eng. Des.;10 (238), 2008, s. 2495-506.

[3] Freiesleben H.P., Pedersen E.J.: Curing of Concrete Structures, CEB Information Bulletin 166, 1985.

[4] Freiesleben H.P., Pedersen E.J.: Maturity Computer for Controlled Curing and Hardening of Concrete, Nordisk Betong, 1 (19), 1977, s. 19-34.

[5] Garbalińska H., Siwińska A.: Ocena porównawcza stacjonarnej i niestacjonarnej techniki pomiaru przewodności cieplnej. Zeszyty Naukowe Politechniki Rzeszowskiej, Budownictwo i Inżynieria Środowiska, z. 47, 2008, s. 123-130.

[6] Glinicki M.A., Jaskulski R., Pichór W., Dąbrowski M., Sobczak M.: Investigation of thermal properties of shielding concretes, Proc. Int. Symp. Brittle Matrix Composites, BMC-11, IPPT PAN, Warszawa, 2015, s. 371-380.

[7] Kiernożycki W.: Betonowe konstrukcje masywne. Teoria, wymiarowanie, realizacja, Polski Cement, Kraków, 2003.

[8] Knor G.: Identyfikacja, modelowanie i sterowanie polami temperatury w konstrukcjach betonowych, rozprawa doktorska, IPPT PAN, Warszawa, 2014

[9] Knor G., Glinicki M.A., Holnicki-Szulc J: Wyznaczanie parametrów termicznych twardniejących betonów za pomocą rozwiązania problemu odwrotnego, Roads and Bridges-Drogi i Mosty, v. 11, n. 4, 2012, s. 281-294.

[10] Mazars J., Capra B., Rouquand A., Pontiroli C.: Concrete properties, safety, and sustainability of nuclear power plant infrastructures: New tools and themes for future research. W: Infrastructure Systems for Nuclear Energy; Hsu, T.T.C., Wu, C.-L., Lin, J.-L., Eds.; John Wiley \& Sons, Hobokon, 2014, s. 103-125.

[11] RILEM: TC 119-TCE: Avoidance of Thermal Cracking in Concrete at Early Ages. Materials and Structures. RILEM 1997, 451-464. 


\section{MONITORING OF THE THERMAL PARAMETERS OF THE HARDENING PROCESS OF SHIELDING CONCRETES}

\section{S u m m a r y}

The article presents the results of thermal parameters monitoring of the hardening process of three concrete mixtures. Two of them were prepared using an aggregate used in the manufacturing of shielding concretes (magnetite and serpentine aggregate) and the third one was the reference one prepared with amphibolite aggregate. Thermal parameters of the hardening process of the concrete were determined on the basis of the measured temperature changes. On the same basis by means of numerical solution of the inverse problem the thermal parameters of concrete mixtures during $72 \mathrm{~h}$ of hardening were determined. Using the same method the heat source function values were determined and on its basis the total quantity of heat released during hydration of cement was estimated. Good compliance of the release functions and the charts of temperature changes in mixtures was obtained. The differences due to different thermal parameters of the aggregates were clearly marked. In the case of mixture with serpentine aggregate significant differences in the course of temperature increase (delay) relative to the other mixtures were observed.

Keywords: fresh concrete, shielding concrete, heat of hydration, specific heat, thermal conductivity.

Przestano do redakcji: 07.06.2016 $r$.

Przyjęto do druku: 30.06.2016r.

DOI: $10.7862 / \mathrm{rb} .2016 .14$ 